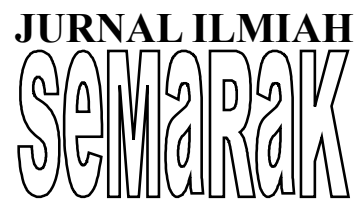

P-ISSN 2615-6849, E-ISSN 2622-3686

Jurnal Semarak,Vol. 2,No.3, Oktober 2019, Hal (61- 77)

(a)Prodi Manajemen Fakultas Ekonomi Universitas Pamulang

\title{
PENGARUH EARNING PER SHARE, SUKU BUNGA (SBI) DAN NILAI TUKAR RUPIAH TERHADAP STOCK RETURN PADA PERUSAHAAN LQ 45 PERIODE 2012 - 2015
}

\author{
Senen \\ Assisten Ahli Fakultas Ekonomi Universitas Pamulang \\ email: dosen01888@unpam.ac.id abdisantosasenen@gmail.com
}

\begin{abstract}
ABSTRAK
Penelitian ini memiliki tujuan untuk mengetahui pengaruh secara parsial antara earning per share terhadap stock return pada perusahaan LQ 45 periode $2012-2015$, untuk mengetahui pengaruh secara parsial antara suku bunga terhadap stock return pada perusahaan LQ 45 periode 2012 - 2015, untuk mengetahui pengaruh secara parsial antara earning per share terhadap stock return pada perusahaan LQ 45 periode $2012-2015$ dan untuk mengetahui pengaruh secara simultan antara earning per share, suku bunga dan nilai tukar rupiah terhadap stock return pada perusahaan LQ 45 periode 2012-2015. Metode penelitian yang digunakan dalam Penelitian ini adalah analisis regresi linier berganda. Data yang digunakan dalam penelitian ini menggunakan data skunder yang diperoleh dari laporan keuangan dan data bank indonesia. Pemilihan sampel pada penelitian ini adalah perusahaan yang berada di BEI yang listing dari tahun 2012 sampa tahun 2015 yang masuk dalam perusahaan LQ 45. Hasil penelitian menyatakan bahwa variabe earning per share secara parsial tidak berpengaruh terhadap return saham sedangkan variabe suku bunga dan kurs memiliki pengaruh secara parsial terhadap return saham. Secara simultan variabel earning per share, suku bunga dan kurs memiliki pengaruh signifikan terhadap return saham. Berdasarkan hasil koefisien determinasi bahwa variabel earning per share, suku bunga dan kurs memiliki pengaruh sebesar 39,7\%. Sẹangkan sisanya 60,3\% dijelaskan dengan faktor atau variabel lain yang tidak diketahui dan tidak termasuk dalam analisis regresi ini, seperti return on asset, debt to equity ratio dan lain-lain.
\end{abstract}

Kata kunci: earning per share, suku bunga, kurs, return saham

\section{ABSTRACT}

This study aims to determine the effect of partial earnings per share on stock returns on LQ 45 companies in the period 2012 - 2015, to determine the partial effect of interest rates on stock returns on LQ 45 companies in the period 2012 - 2015, to determine the effect partially between earnings per share of stock returns in LQ 45 companies in the period 2012 - 2015 and to know the effect simultaneously between earnings per share, interest rates and rupiah exchange rates on stock returns in LQ 45 companies for the period 2012 - 2015. The research methods used in the study this is multiple linear regression analysis. The data used in this study uses secondary data obtained from financial reports and Indonesian bank data. The sample selection in this study is a company that is on the IDX whose listings from 2012 to 2015 are included in LQ 45 companies. The results of the study state that the earnings per share variable partially does not affect stock returns while the interest rate and exchange rate variables have an partial to stock returns. Simultaneously earning per share variable, interest rate and exchange rate have a significant effect on stock returns. Based on the results of the coefficient of determination that the earnings per share variable, interest rate and exchange rate have an influence of $39.7 \%$. While the remaining $60.3 \%$ is explained by other factors or variables unknown and not included in this regression analysis, such as return on assets, debt to equity ratio and others.

Keywords: earning per share, interest rates, exchange rates, stock return.

I. PENDAhUluan

\section{A. Latar Belakanng}

Perkembangan pelaburan ini sudah begitu pesatnya terutama pada pasar keuangan di indonesia. Hal ini ditandai dengan jumlah perusahaan yang telah pergi ke masyarakat yang semakin bertambah. Secara dasarnya pelaburan adalah suatu kegiatan yang terus menempatkan dana dengan harapan untuk memperoleh tambahan atau keuntungan. Pada umumnya pelaburan kewangan terbagi menjadi dua bahagian pasaran modal dan pasar uang. Pembagian ini di atas instrumen kewangan atau surat 


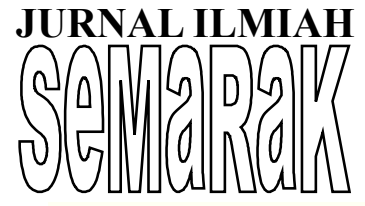

berharga yang diperjualbelikan (Sinaga, 2006: 13).

Pelabur mempunyai banyak pilihan dalam menginvestasikan dana dalam pasaran modal dan pasar uang. Namun dalam pembuatan keputusan investasi, investor mempertimbangkan faktor-faktor yang mempengaruhi tingkat pengembalian investasinya dimasa yang akan datang, untuk itu keputusan investasi dibuat harus berdasarkan analisis dan perhitungan yang matang. Hartanah dunia dan pasar modal mempunyai hubungan yang saling berkaitan kerana pelabur dapat mengambil keputusan melakukan kegiatan investasinya dalam bentuk saham / obligasi. Perubahan ini bergantung pada pulangan, dan risiko yang ditanggung pelabur. Gejolak pasar modal mencerminkan perubahan perilaku pelabur dalam berinvestasi Perdana, dkk, 2006:2)

Tujuan seorang pengurus adalah memksimalkan nilai saham perusahaanya. Nilai tersebut diukur pada aliran tunai yang akan menghasilkan syarikat di masa hadapan (Brigham dan Housthon 2010: 83). Rasio kewangan sebagai instrumen analisis prestasi syarikat yang menjelaskan berbagai hubungan dan indikator keuangan, yang ditujukan untuk menunjukkan perubahan dalam kondisi keuangan atau prestasi operasi di masa lalu dan membantu menggambarkan trend perubahan pola tersebut, untuk kemudian menunjukkan risiko dan peluang yang melekat pada perusahaan yang bersangkutan. Hal ini menunjukkan bahawa analisis rasio kewangan, walaupun berdasarkan data dan kondisi masa lalu tetapi dimaksudkan untuk menilai risiko dan peluang di masa yang akan dating (Apriliana, 2008:2).

Kajian Hardiningsih, dkk (2001), menunjukkan bahwa nilai tukar rupiah / dolar AS berpengaruh negatif terhadap saham pulangan sedangkan penelitian Nurdin (1999) menunjukkan bahwa nilai tukar Rupiah / US Dollar tidak berpengaruh terhadap risiko investasi saham (Meta, 2006: 2). Berdasarkan hasil penelitian Purwiani (2007) dalam Ali Sadikin (2011: 24) tentang pengaruh risiko kurs dan risiko suku bunga berpengaruh secara signifikan terhadap return saham. Dimana risiko pasaran dan risiko kurs rupiah berpengauh signifikan terhadap pulangan saham dengan arah positif, sedangkan risiko suku bunga berpengaruh terhadap pulangan saham tetapi dengan arah negatif. Bilson, Brailsford dan Hooper (2001) menggunakan indeks pasaran indeks ketinggian nilai dan beberapa makroekonomi yang berbeza untuk menjelaskan saham kembali. Hasil dari kajian tersebut menyarankan harga barangan dan realitas memiliki kemampuan yang terbatas dalam menjelaskan variasi dari return. Sementara itu, bekalan wang, nilai tukar, dan pulangan pasaran menjadi sangat signifikan dalam menjelaskan kembali. Wongbangpo dan Sharma (2002) menguji hubungan antara harga saham dan beberapa faktor makroekonomi di lima negara ASEAN (Indonesia, Malaysia, Filiphina, Singapura, dan Thailand). Hasil daripada kajian tersebut menyatakan bahawa harga saham dalam jangka 
panjang mempunyai hubungan yang positif terhadap pertumbuhan output dalam jangka panjang. Dalam jangka pendek, harga saham dijumpai sebagai fungsi dari nilai makroekonomi dalam masa lalu dan saat ini. Kajian mengenai makroekonomi juga dilakukan oleh Lestari (2005) yang menyatakan bahwa menunjukkan makroekonomi variabel terhadap return saham tidak terpengaruh signifikan. Namun dengan menggunakan model kausalitas granger hasil penelitianya menunujuk bahwa varibel makro tersebut mempengaruhi saham kembali .

Dalam menganalisis kinerja keuangan cukup banyak diantaranya return on asset, total asset turover, earning per share dan lain-lain. "Return On Assets (ROA) adalah rasio profitabilitas yang menunjukan perbandingan antara laba (sebelum pajak) dengan total asset bank, rasio ini menunjukan tingkat efisiensi pengelolaan asset yang dilakukan oleh bank yang bersangkutan” (Riyadi, 2003:137). Kinerja keuangan yang dapat mempengaruhi return saham lainya adalah total asset turnover, total asset turnover menunjukkan bagaimana efektifitas perusahaan menggunakan keseluruhan aktiva untuk meningkatkan nilai penjualan dan meningkatkan laba (Sartono, 2001:122). Nilai rasio TATO yang tinggi menunjukkan semakin efisien suatu perusahaan dalam memanfaatkan aktiva yang dimiikinya dan menunjukkan semakin besar penjualan yang dihasilkan. Nilai TATO yang tinggi akan mengurangi ketidakpastian investor dalam menanamkan dananya. Dari penjualan yang tinggi diharapkan dapat dihasilkan return yang tinggi pula.

Prestasi kewangan lainya adalah pendapatan per saham, pendapatan per saham (EPS) adalah perbandingan antara pendapatan (dalam hal ini laba bersih setelah pajak) dengan jumlah perusahaan saham. Bagi para pelabur, EPS maklumat merupakan informasi yang dianggap paling fundamental dan berguna, karena dapat menggambarkan prospek pendapatan di perusahaan masa depan (Tandelin, 2001). Earning Per Share (EPS) menunjukkan tingkat keuntungan yang diperoleh untuk setiap saham. EPS semakin besar menyebabkan semakin besar laba yang diterima oleh pemegang saham, hal itu menunjukkan semakin baik keadaan operasional perusahaan (Darmadji dan Fakhruddin, 2006:195).

Berdasarkan penjelasan yang telah diuraikan di atas, maka penulis tertarik untuk melakukan penelitian dengan judul "Pengaruh Earning Per Share, Suku Bunga (SBI) Dan Nilai Tukar Rupiah Terhadap Stock Return Pada Perusahaan LQ 45 Periode 2012 2015".

\section{B. Perumusan Masalah}

Berdasarkan batasan masalah diatas, maka masalah-masalah penelitian dapat dirumuskan sebagai berikut:

1. Apaakah terrdapat peengaruh secara parsial antara earning per share terhadap stock return pada perusahaan LQ 45 periode $2012-2015$ ? 


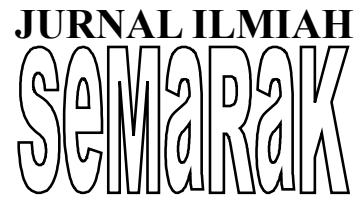

2. Apakaah terdapayt pengaruh secara parsial antara suku bunga terrhadap stock return pada perusahaan LQ 45 periode $2012-2015$ ?

3. Apakkah terddapat penngaruh secara parsial antara earning per share trhadap stock return pada perusahaan LQ 45 periode 2012 - 2015 ?

4. Apakah terdapat pengaruh secara simultan antara earning per share, suku bunga dan nilai tukar rupiah terhadap stock return pada perusahaan LQ 45 periode $2012-2015$ ?

\section{Tujuan Penelitian}

Berdasarkan latar belakang masalah dan perumusan masalah, maka tujuan dalam penelitian ini adalah sebagai berikut:

1. Untuk mengetahui pengaruh secara parsial antara earning per share terhadap stock return pada perusahaan LQ 45 periode $2012-2015$.

2. Untuk mengetahui pengaruh secara parsial antara suku bunga terhadap stock return pada perusahaan LQ 45 periode $2012-2015$.

3. Untuk mengetahui pengaruh secara parsial antara earning per share terhadap stock return pada perusahaan LQ 45 periode $2012-2015$.

4. Untuk mengetahui pengaruh secara simultan antara earning per share, suku bunga dan nilai tukar rupiah terhadap stock return pada perusahaan LQ 45 periode $2012-2015$.

\section{TINJAUAN PUSTAKA}

\section{A. Manajemen}

Manajemen berasal dari kata bahasa inggris "management" dengan kata kerja " to mange" yang secara umum artinya mengurus.James A.F. Stoner menyatakan bahwa :

Manajemen adalah proses perencanaan, pengorganisasian, pengarahan dan pengendalian anggota organisasi dalan proses penggunaan nilainilai sumber daya organisasi lainnya untuk tercapainya tujuan organisasi yang telah ditetapkan.

Sedangkan menurut Hasibuan (2005: 9)) "Manajemen adalah ilmu dan seni mengatur proses pemanfaatan sumber daya manusia dan sumber-sumber daya lainnya secara efektif dan efesien untuk mencapaian suatu tujuan tertentu".

Berdasarkan definisi di atas, penulis menyimpulkan bahwa manajemen adalah suatu langkah yang terpadu, yang mengembangkan suatu organisasi sebagai ilmu dan seni mengatur proses pemanfatan sumber daya manusia dan sumber daya lainnya secara efektif dan efesien untuk mencapai suatu tujuan tertentu.

Menurut George R. Terry (2007:17) menyatakan bahwa : "Management is a distinc process consisting of a planing, organizing, actuating and controling, performend todetermint and accomplish stated objectives by the use of human being and other resources". (Manajemen adalah suatu proses tertentu yang terdiri 
atas perencanaan, pengorganisasian, penggerakan, dan pengawasan yang dilakukan untuk menentukan dan mencapai matlamat yang ditetapkan oleh manusia dan sumber lain).

Manajemen ini terdiri dari enam unnsur (6 M) yaitu meen, monney, metthode, materials, machines, dan market. Unsur meen (manuusia) ini berkemmbang mennjadi suattu bidang ilmu manajemen yang di sebut mannajemen suumber daaya maanusia atau disingkat MSDM.

Berdasaran pendapat para ahli diatas penulis dapat menyimpulkan bahwa manajemen adalah proses pengelolaan kegiatan seorang pimpinan dalam perencanaan pengorganisasian, pengkoordinasian dan pengawasan dengan menggunakan kemampuan daan keterampilan ilmiahnya, menggerakan orang-orang untuk bekerja dalam rangka untuuk memperoleh hasil dan mencaapai tujuan yaang teelah ditettapkan semua denggan memanfatkan sumber-sumber yang ada.

\section{B. Manajemen Keuangan}

Setiap perusahaan
membutuhkan dana dalam rangka
memenuhi kebutuhan operasi sehari-hari
maupun untuk mengembangkan
perusahaan. Kebutuhan dana tersebut
berupa modal kerja maupun untuk
pembelian aktiva tetap. Untuk memenuhi

kebutuhan dana tersebut, perusahaan harus mampu mencari sumber dana dengan komposisi yang menghasilkan beban biaya paling murah. Kedua hal tersebut harus bisa diupayakan oleh manajer keuangan.

Menurut (Sartono, 2010:6) "manajemen keuangan dapat diartikan sebagai manajemen dana baik yang berkaitan dengan pengalokasian dana dalam berbagai bentuk investasi secara efektif maupun usaha pengumpulan dana untuk pembiayaan investasi atau pembelanjaan secara efisien".

Menurut (Husnan, 2010:3) "manajemen keuangan adalah suatu kegiatan perencanaan, penganggaran. Pemeriksaan, pengelolaan, pengendalian, pencarian dan penyimpanan dana yang dimiliki oleh suatu organisasi atau perusahaan".

Berdasarkan pendapat para ahli di atas, maka dapat disimpulkan bahwa manajemen keuanagan adalah "manajemen dana, baik berkaitan dengan pengalokasian dana dalam berbagai bentuk investasi secara efektif dengan kegiatan perencanaan, penganggaran. Pemeriksaan, pengelolaan, pengendalian, pencarian dan penyimpanan dana yang dimiliki oleh suatu organisasi atau perusahaan. Tujuan utama manajemen keuangan suatu perusahaan adalah untuk memaksimalkan laba yang akan diperoleh dan memaksimumkan kesejahteraan para pemegang saham yang dapat diukur dari 


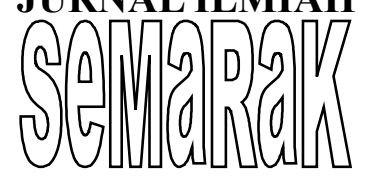

harga saham perusahaan tersebut. Menurut (Sartono, 2010:15), Tujuan dari manajemen keuangan yaitu:

1. Memaksimumkan Profit

Tujuan pokok pada umumnya yang ingin dicapai oleh seorang manajer keuangan adalah memaksimumkan laba (profit). Namun tujuan seperti ini memiliki banyak kelemahan. Pertama, standar ekonomi memaksimumkan laba bersifat statis. Kedua, pengertian dari laba tersebut dapat menyesatkan, ketiga merupakan risiko yang berkaitan dengan setiap alternatif pengambilan keputusan.

2. Memaksimumkan Kemakmuran Para Pemegang Saham

Merujuk pada kelemahankelemahan tersebut, maka sebaiknya tujuan yang harus dicapai oleh seorang manajer keuangan bukanlah memaksimumkan laba, akan tetapi memaksimumkan kemakmuran para pemegang saham (Maximization Wealth of Stockholders) dengan memaksimumkan nilai perusahaan. Memaksimumkan kemakmuran para pemegang saham dapat ditempuh dengan memaksimumkan nilai sekarang (present value) dari semua keuntungan pemegang saham yang diharapkan akan diperoleh pda masa yang akan datang. Kemakmuran para pemegang saham akan meningkat jika harga saham yang dimilikinya meningkat pula.

Dalam menjalankan fungsinya, tugas dari seorang manajer keuangan berkaitan dengan keputusan pokok perusahaan dan berpengaruh terhadap nilai perusahaan. Menurut (Syamsudin, 2010:8) fungsi manajemen keuangan adalah:

1. Menganalisa dan merencanakan pembelanjaan perusahaan.

2. Mengelola penanaman modal dalam aktiva, dan

3. Mengatur struktur financial dan struktur modal perusahaan.

Menurut (Sartono, 2010:6), pada prinsipnya fungsi utama manajemen keuangan sebagai berikut :

1. Pengambilan keputusan investasi

Fungsi pertama menyangkut tentang keputusn alokasi dana baik dana yang berasal dari dalam perusahaan maupun dana yang berasal dari luar perusahaan pada berbagai bentuk investasi. Investasi dapat berupa investasi jangka pendek maupun investasi jangka panjang.

2. Pengambilan keputusan pembelanjaan

Fungsi kedua mengangkut tentang pengambilan keputusan pembelanjaan. Peran manajemen keuangan dalam pemenuhan kebutuhan dana menjadi semakin komplek dalam kondisi globalisasi pasar modal. Pengumpulan dana tidak lagi terbatas pada satu negara melainkan kesempatan untuk 
manarik dana dari investor asing. Pemahaman dapat mengurangi ketergantungan dana dari perbankan melalui penemuan baru instrumen pasar uang dan pasar modal.

3. Kebijakan dividen

Fungsi ketiga yaitu kebijakan dividen, memang pada prinsipnya kebijakan dividen ini menyangkut tentang keputusan apakah laba yang diperoleh perusahaan seharusnya dibagikan kepada pemegang saham dalam bentuk dividen kas dan pembelian kembali saham atau laba tersebut sebaiknya ditahan dalam bentuk laba ditahan guna pembelanjaan investasi dimasa yang akan datang.

\section{EPS (Earning Per Share)}

Earning Per Share merupakan rasio yang menunjukan bagian laba untuk setiap saham. Earning Per Share (EPS) menggambarkan profitabilitas perusahaan yang tergambar pada setiap lembar saham. Semakin tinggi nilai Earning Per Share tentu saja menyebabkan semakin besar laba dan kemungkinan peningkatan jumlah dividen yang diterima pemegang saham (Tjiptono, 2006:195). Umumnya perhitungan Earning Per Share menggunakan basis laporan keuangan akhir tahun (auditan) namun dapat pula menggunakan laporan keuangan tengah tahun atau laporan keuangan kuartalan. Dalam prakteknya, laba per saham dihitung dengan membagi laba bersih dengan jumlah rata-rata tertimbang dari jumlah saham biasa yang beredar sepanjang tahun. Jumlah rata-rata dipergunakan dalam perhitungan karena jumlah saham beredar selama satu tahun tidak selalu tetap atau dengan kata lain, jumlah saham beredar dapat berubah (Tjiptono, 2006:196). Earning Per Share (EPS) yaitu merupakan rasio yang menunjukkan berapa besar keuntungan laba yang diperoleh investor atau pemegang saham per lembar sahamnya (Bodie, 2006:220).

EPS ini akan sangat membantu investor karena informasi EPS ini bisa menggambarkan prospek earning suatu perusahaan dimasa yang akan datang karena EPS menunjukkan laba bersih perusahaan yang siap dibagikan kepada semua pemegang saham perusahaan, maka semakin besar EPS akan menarik investor untuk melakukan investasi diperusahaan tersebut. Oleh karena itu, hal tersebut akan mengakibatkan permintaan akan saham meningkat dan harga saham akan meningkat, dengan demikian EPS berpengaruh positif terhadap return saham (Yeye Sulilowati 2011:24).

\section{Nilai Tukar Rupiah}

Nilai tukar menunjukkan banyaknya unit mata uang yang dapat dibeli dan ditukar dengan satu satuan mata uang lain (Sartono, 2001). Nilai tukar rupiah adalah harga rupiah terhadap mata uang negara lain. Jadi, nilai tukar rupiah merupakan 
nilai dari satu mata rupiah yang ditranslasikan ke dalam mata uang negara lain.Misalnya nilai tukar rupiah terhadap Dolar AS, nilai tukar rupiah terhadap Yen,dan lain sebagainya. Dalam transaksi valuta asing dibedakan menjadi dua jenis kurs yaitu kurs spot (spot rate) dan kurs berjangka (forward rate). Dari kedua jenis transaksi tersebut, transaksi valuta asing yang paling dikenal transaksi seketika (on the spot). Transaksi spot yang lazim digunakan dalam melakukan pembayaran dan penerimaan valuta asing adalah dalam jangka waktu dua hari kerja setelah disepakatinya transaksi tersebut. Sedangkan transaksi berjangka (forward transaction) merupakan kesepakatan yang dicapai pada hari ini namun baru berlaku beberapa waktu kemudian (misalnya 3 bulan). Dalam penelitian ini kurs yang dipakai adalah kurs spot (spot rate). (Subalno, 2010).

Kurs inilah sebagai salah satu indikator yang mempengaruhi aktivitas dipasar saham maupun pasar uang karena investor cenderung akan berhati-hati untuk melakukan investasi. Menurunnya kurs Rupiah terhadap mata uang asing khususnya Dolar AS memiliki pengaruh negatif terhadap ekonomi dan pasa rmodal (Sitinjak dan Kurniasari, 2003).

\section{E. Suku Bunga Bank Indonesia (SBI)}

Tingkat bunga dalam investasi akan menjadi pedoman yang penting dalam pertimbangan pengambilan keputusan.
Umumnya tingkat bunga akan memiliki hubungan negatif dengan kinerja saham. Bila pemerintah mengumumkan kenaikan tingkat bunga akan meleihi harapan imbal hasil dalam saham maka para investor akan beraksi dengan menjual saham dan menggantinya dengan sekuritas berpendapatan tetap (deposito) yang memberi imbal hasil (bunga) lebih tinggi. Suku bunga dan prakiraan nilainya di masa depan merupakan salah satu masukan yang penting dalam keputusan investasi (Bodie, 2006:180).

Menurut Karl dan Fair (2001:635) suku bunga adalah pembayaran bunga tahunan dari suatu pinjaman, dalam bentuk persentase dari pinjaman yang diperoleh dari jumlah bunga yang diterima tiap tahun dibagi dengan jumlah pinjaman. Suku bunga merupakan harga dari pinjaman. Suku bunga dinyatakan sebagai persentase uang pokok per unit waktu. Bunga merupakan suatu ukuran harga sumber daya yang digunakan oleh debitur yang harus dibayarkan kepada kreditur (Sunariyah, 2004:80).

Menurut Prasetiantono (2000:97) mengenai suku bunga adalah jika suku bunga tinggi, otomatis orang akan lebih suka menyimpan dananya di bank karena ia dapat mengharapkan pengembalian yang menguntungkan. Dan pada posisi ini, permintaan masyarakat untuk memegang uang tunai menjadi lebih rendah karena mereka sibuk mengalokasikannya ke 


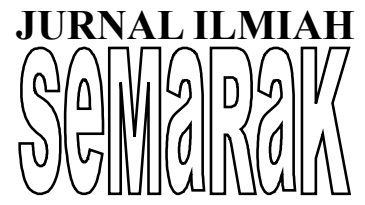

dalam bentuk portfolio perbankan (deposito dan tabungan). Seiring dengan berkurangnya jumlah uang beredar, gairah belanja pun menurun. Selanjutnya harga barang dan jasa umum akan cenderung stagnan, atau tidak terjadi dorongan inflasi. Sebaliknya jika suku bunga rendah, masyarakat cenderung tidak tertarik lagi untuk menyimpan uangnya di bank. Beberapa aspek yang dapat menjelaskan fenomena tingginya suku bunga di Indonesia adalah tingginya suku bunga terkait dengan kinerja sektor perbankan yang berfungsi sebagai lembaga intermediasi (perantara), kebiasaan masyarakat untuk bergaul dan memanfaatkan berbagai jasa bank secara relatif masih belum cukup tinggi, dan sulit untuk menurunkan suku bunga perbankan bila laju inflasi selau tinggi (Prasetiantono, 2000:99-101).

\section{F. Hipotesis Penelitian}

Hipotesis yang diuji dalam penelitian ini berkaitan dengan ada atau tidaknya pengaruh yang signifikan dari seperangkat variabel bebas (independent variable) terhadap variabel terikat (dependent variable). Adapan hipotesis yang diuji yakni sebagai berikut:

1. $\mathrm{H}_{\mathrm{o}}$ : variabel earning per share tidak berpengaruh secara parsial terhadap stock return.

$\mathrm{H}_{\mathrm{a}} \quad$ : variabel earning per share berpengaruh secara parsial terhadap stock return.
2. $\mathrm{H}_{\mathrm{o}}$ : variabel nilai tukar rupiah tidak berpengaruh secara parsial terhadap stock return.

$\mathrm{H}_{\mathrm{a}} \quad$ : variabel nilai tukar rupiah berpengaruh secara parsial terhadap stock return.

3. $\mathrm{H}_{\mathrm{o}}$ : variabel suku bunga bank indonesia (SBI) tidak berpengaruh secara parsial terhadap stock return.

$\mathrm{H}_{\mathrm{a}} \quad$ : variabel suku bunga bank indonesia (SBI) berpengaruh secara parsial terhadap stock return.

4. $\mathrm{H}_{\mathrm{o}}$ : variabel earning per share, nilai tukar rupiah dan suku bunga bank Indonesia (SBI) tidak berpengaruh secara simultan terhadap stock return.

$\mathrm{H}_{\mathrm{a}} \quad$ : variabel earning per share, nilai tukar rupiah dan suku bunga bank Indonesia (SBI) berpengaruh secara simultan terhadap stock return.

\section{METODE PENELITIAN}

Objek dalam penelitian ini adalah perusahaan LQ 45 yang terdaftar di bursa efek Indonesia (BEI). Metode yang digunakan dalam penelitian ini adalah metode studi kasus yang merupakan salah satu penelitian deskriptif, dengan studi ini diharapkan dapat diungkap secara mendalam variabel-variabel yang akan dapat menggambarkan tentang analisis earning per share, nilai tukar 
rupiah dan suku bunga bank Indonesia (SBI) terhadap stock return.

Data-data yang digunakan dalam penelitian ini, baik yang bertujuan untuk mendeskripsikan maupun untuk menganalisis, diperoleh dari data sekunder yang bersifat kuantitatif. Data sekunder adalah data yang informasinya diperoleh secara tidak langsung dari perusahaan. Sedangkan menurut Kuncoro (2011:31), data sekunder adalah sumber data penelitian yang diperoleh peneliti secara tidak langsung melalui perantara (diperoleh dan dicatat oleh pihak lain). Data-data sekunder tersebut berupa rasio-rasio laporan keuangan dari laporan keuangan perusahaan yang telah diaudit di Bursa Efek Indonesia (BEI) per 31 desember 2012 - 2015.

sampel yang digunakan dengan metode purposive sampling. Metode purposive sampling yaitu sampel yang diambil berdasarkan kriteria-kriteria tertentu untuk mendapatkan sampel yang sesuai dengan tujuan penelitian (Yama dan Adityawati, 2009:287). Sampel dalam penelitian ini ditentukan berdasarkan beberapa kriteria atau pertimbangan sebagai berikut: 1) perusahaan yang telah terdaftar di Bursa Efek Indonesia dalam kurung waktu 2010 sampai 2014, 2) Perusahaan mempublikasikan laporan keuangan yang telah diaudit dengan menggunakan tahun buku yang berakhir pada tanggal 31 Desember, 3) Perusahaan LQ 45 yang terdaftar di Bursa Efek Indonesia
Teknik pengumpulan data dengan menggunakan analisis laporan keuangan. Sampel yang dijadikan objek penelitian sebanyak 17 perusahaan LQ 45 yang terdaftar di BEI.

\section{HASIL DAN PEMBAHASAN}

\section{A. Gambaran Objek Penelitian}

Indeks LQ 45 adalah nilai kapitalisasi pasar dari 45 saham yang paling likuid dan memiliki nilai kapitalisasi yang besar hal itu merupakan indikator likuidasi. Indeks LQ 45, menggunakan 45 saham yang terpilih berdasarkan Likuiditas perdagangan saham dan disesuaikan setiap enam bulan (www.idx.co.id).

Tujuan indeks LQ 45 adalah sebagai pelengkap IHSG dan khususnya untuk menyediakan sarana yang obyektif dan terpercaya bagi analisis keuangan, manajer investasi, investor dan pemerhati pasar modal lainnya dalam memonitor pergerakan harga dari saham-saham yang aktif diperdagangkan. Dengan demikian saham yang terdapat dalam indeks tersebut akan selalu berubah. Beberapa kriteria kriteria seleksi untuk menentukan suatu emiten dapat masuk dalam perhitungan indeks LQ 45 adalah:

1. Kriteria yang pertama adalah:

a. Berada di TOP $95 \%$ dari total rata rata tahunan nilai transaksi saham di pasar reguler.

b. Berada di TOP $90 \%$ dari rata - rata tahunan kapitalisasi pasar.

2. yang kedua adalah: 
a. Merupakan urutan tertinggi yang mewakili sektor dalam klasifikasi industri BEJ sesuai dengan nilai kapitalisasi pasarnya.

b. Merupakan urutan tertinggi berdasarkan frekuensi transaksi (Tjiptono, 2001:95-96).

Indeks LQ 45 hanya terdiri dari 45 saham yang telah terpilih melalui berbagai kriteria pemilihan, sehingga akan terdiri dari saham-saham dengan likuiditas dan kapitalisasi pasar yang tinggi. Sahamsaham pada indeks LQ 45 harus memenuhi kriteria dan melewati seleksi utama sebagai berikut:

1. Masuk dalam ranking 60 besar dari total transaksi saham di pasar reguler (rata-rata nilai transaksi selama 12 bulan terakhir).

2. Ranking berdasar kapitalisasi pasar (rata-rata kapitalisasi pasar selama 12 bulan terakhir)

3. Telah tercatat di BEJ minimum 3 bulan

4. Keadaan keuangan perusahaan dan prospek pertumbuhannya, frekuensi dan jumlah hari perdagangan transaksi pasar reguler.

Saham-saham yang termasuk didalam LQ 45 terus dipantau dan setiap enam bulan akan diadakan review (awal Februari, dan Agustus). Apabila ada saham yang sudah tidak masuk kriteria maka akan diganti dengan saham lain yang memenuhi syarat. Pemilihan saham saham LQ 45 harus wajar, oleh karena itu
BEJ mempunyai komite penasehat yang terdiri dari para ahli di BAPEPAM, Universitas, dan Profesional di bidang pasar modal (www.idx.co.id).

\section{B. Hasil Analisis dan Pembahasan}

\section{Hasil Uji Asumsi Klasik}

\section{a. Hasil Uji Normalitas Data}

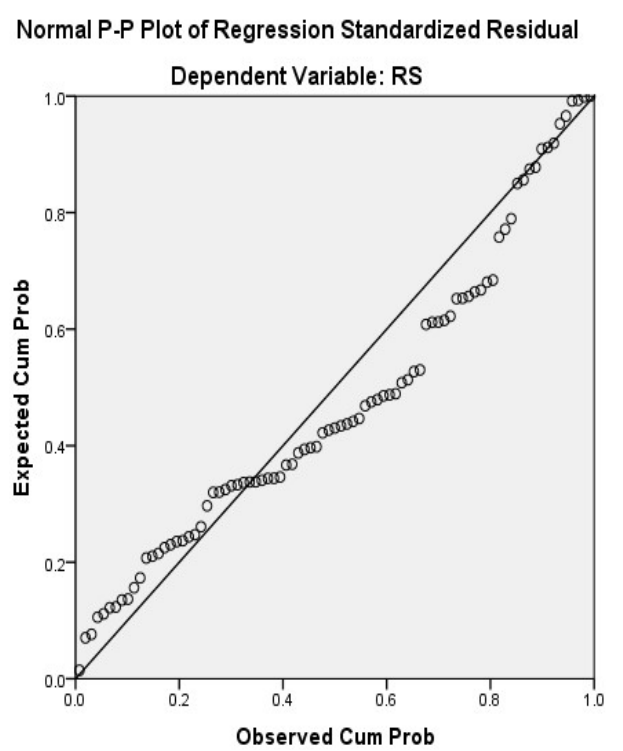

Gambar 1

Hasil Uji Normalitas Data

Dari grafik di atas dapat dilihat bahwa data penelitian memiliki penyebaran dan distribusi yang normal karena data memusat pada nilai rata-rata dan median atau nilai plot PP terletak digaris diagonal, maka dapat dikatakan bahwa data tersebut berdistribusi normal.

\section{b. Hasil Uji Multikolinearitas}

Tabel 1

Hasil Uji Multikolinearitas 


\begin{tabular}{|c|c|c|c|}
\hline \multirow{3}{*}{ Mode } & \multicolumn{3}{|c|}{ Coefficients } \\
\hline & & \multicolumn{2}{|c|}{ Collinearity Statistics } \\
\hline & & Tolerance & VIF \\
\hline \multirow{4}{*}{1} & (Constant) & & \\
\hline & EPS & 1.000 & 1.000 \\
\hline & SBI & .127 & 7.893 \\
\hline & KURS & .127 & 7.893 \\
\hline
\end{tabular}

Nilai VIF yang diperbolehkan hanya mencapai 10 dan memiliki nilai tolerance lebih dari 0,10 . Maka data di atas dapat dipastikan tidak terjadi gejala multikolinearitas. Karena data di atas menunjukan bahwa nilai VIF lebih kecil dari 10.

\section{c. Hasil Uji Autokorelasi}

Tabel 2

Hasil Uji Autokorelasi

\begin{tabular}{|l|r|r|r|r|r|}
\hline Model & $R$ & R Square & $\begin{array}{l}\text { Adjusted } \\
\text { R Square }\end{array}$ & $\begin{array}{r}\text { Std. Error of } \\
\text { the Estimate }\end{array}$ & Durbin-Watson \\
\hline 1 & $.647^{\circ}$ & .419 & .397 & .62352 & 1.792 \\
\hline
\end{tabular}

Pada tabel di atas diketahui nilai Durbin Watson (d) sebesar 1,792 nilai ini akan dibandingkan dengan nilai tabel dengan menggunakan nilai signifikansi $5 \%$, jumlah sampel (n) 85 dan jumlah variabel independen $(\mathrm{k})$ adalah 3 . Maka dari tabel didapat nilai $\mathrm{du}=$ 1,721 dan $4-\mathrm{du}=4-1,721=2,28$. Oleh karena nilai $\mathrm{du}<\mathrm{d}<4$-du atau $1,721<1,792<2,28$ maka dapat disimpulkan tidak ada autokorelasi baik positif maupun negatif.

\section{d. Hasil Uji Heteroskedastisitas}

\section{Gambar 2}

Hasil Uji Heteroskedastisitas

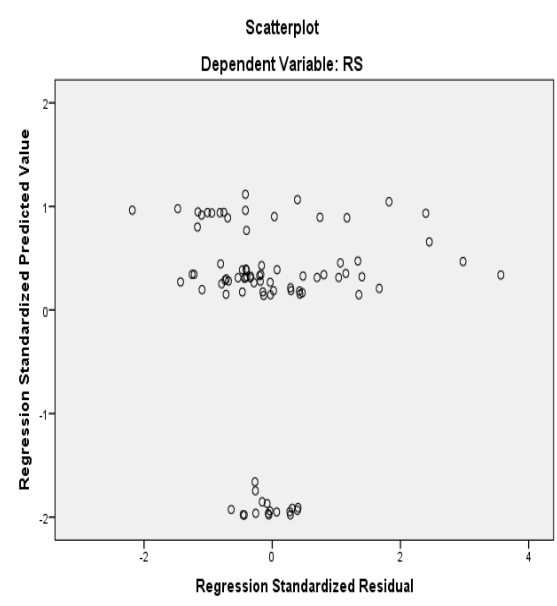

Pada gambar di atas terlihat bahwa titik-titik menyebar di atas dan di bawah angka nol pada sumbu $\mathrm{Y}$ dan tidak terlihat pola tertentu. Dengan demikian pada persamaan regresi linier berganda dalam model ini tidak ada gejala atau tidak ada heteroskedastisitas.

\section{Hasil Analisis Koefisien Regresi Linier Berganda}

a. Hasil Koefisien Determinasi

Tabel 3

Hasil Koefisien

Determinasi (Adjusted $\mathbf{R}^{2}$ )

\begin{tabular}{|l|r|r|r|r|r|}
\hline Model & $R$ & R Square & $\begin{array}{l}\text { Adjusted } \\
\text { R Square }\end{array}$ & $\begin{array}{r}\text { Std. Error of } \\
\text { the Estimate }\end{array}$ & Durbin-Watson \\
\hline 1 & $.647^{\circ}$ & .419 & .397 & .62352 & 1.792 \\
\hline a. Predictors: (Constant), KURS, EPS, SBI \\
\hline
\end{tabular}

Berdasarkan kepada tabel di atas diketahui nilai Adjusted $R$ square sebesar 0,397 (39,7\%), Ini menunjukkan bahwa dengan menggunakan model regresi yang didapatkan dimana variabel independen yaitu earning per share, suku bunga dan kurs memiliki pengaruh terhadap variabel return 
saham sebesar 39,7\%. Sedangkan sisanya $60,3 \%$ dijelaskan dengan faktor atau variabel lain yang tidak diketahui dan tidak termasuk dalam analisis regresi ini, seperti return on asset, debt to equity ratio dan lainlain.

\section{b. Hasil Koefisien Persamaan Regresi Linier Berganda}

Analisis regresi linier berganda adalah suatu uji yang digunakan untuk mengetahui seberapa besar tingkat pengaruh antar variabel independen (earning per share, suku bunga dan kurs) terhadap variabel dependen (return saham). Adapun hasil regresi linier berganda pengaruh earning per share, suku bunga dan kurs terhadap return saham adalah sebagai berikut:

Tabel 4

Hasil Koefisien Persamaan Regresi Linier Berganda

\begin{tabular}{|c|c|c|c|c|}
\hline & & Coefficie & ints & \\
\hline Mod & & $\begin{array}{l}\text { Unstand } \\
\text { Coeffi }\end{array}$ & $\begin{array}{l}\text { ardized } \\
\text { cients }\end{array}$ & $\begin{array}{l}\text { Standardized } \\
\text { Coefficients }\end{array}$ \\
\hline & & $B$ & \begin{tabular}{|l|} 
Std. Error \\
\end{tabular} & Beta \\
\hline & (Constant) & 28.210 & 3.672 & \\
\hline 1 & EPS & 7.405E-005 & .000 & .068 \\
\hline & SBI & -.751 & .103 & -1.732 \\
\hline & KURS & -.003 & .000 & -1.799 \\
\hline
\end{tabular}

Tabel di atas dapat dirumuskan suatu persamaan regresi untuk mengetahui pengaruh earning per share, suku bunga dan kurs terhadap return saham sebagai berikut:

$\mathrm{Y}=\mathrm{a}+b \mathrm{x}_{1}+\mathrm{bx}_{2}+\mathrm{bx}_{3}+\mathrm{bx}$

$\mathrm{Y}=28,210+7,40 \mathrm{X}_{1}+0,751 \mathrm{X}_{2}+$ $0,003 \mathrm{X}_{3}$
Keterangan:

Y : Return Saham

$\mathrm{X}_{1}$ : Earning Per Share

$\mathrm{X}_{2}$ : Suku Bunga (SBI)

$\mathrm{X}_{3}:$ KURS

Koefisien - koefisien persamaan regresi linier berganda di atas dapat diartikan koefisien regresi untuk konstan sebesar 28,210 menunjukkan bahwa jika variabel earning per share, suku bunga dan kurs bernilai nol maka nilai return saham adalah 28,210 satuan. Dengan catatan variabel lain dianggap konstan. Variabel earning per share 7,40 menunjukkan bahwa jika variabel earning per share meningkat 1 satuan maka akan meningkatkan return saham sebesar 7,40 satuan. Variabel SBI 0,751 menunjukkan bahwa jika variabel SBI meningkat 1 satuan maka akan meningkatkan return saham sebesar 0,751 satuan. Variabel KURS 0,003 menunjukkan bahwa jika vaiabel KURS meningkat 1 satuan maka akan meningkatkan return saham sebesar 0,003 satuan, dengan catatan variabel lain dianggap konstan.

\section{Hasil Uji Hipotesis}

\section{a. Hasil Uji Statistik F (Simultan)}

Uji $\mathrm{F}$ dilakukan untuk melihat pengaruh variabel earning per share, suku bunga dan kurs secara 


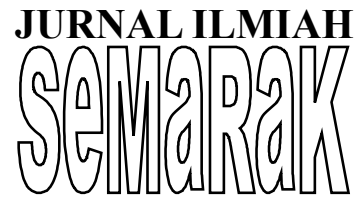

keseluruhan terhadap variabel return saham. Berikut ini adalah hasil uji secara simultan, diperoleh hasil uji Anova sebagai berikut:

\section{Tabel 5}

Hasil Uji Statistik F (Simultan)

\begin{tabular}{|c|c|c|c|c|c|c|}
\hline \multicolumn{7}{|c|}{ ANOVA } \\
\hline Model & & Sum of Squares & df & Mean Square & $F$ & Sig. \\
\hline \multirow{3}{*}{1} & Regression & 22.686 & 3 & 7.562 & 19.451 & $.000^{b}$ \\
\hline & Residual & 31.491 & 81 & .389 & & \\
\hline & Total & 54.176 & 84 & & & \\
\hline
\end{tabular}

Dari data di atas diperoleh hasil nilai signifikan sebesar 0,000 ini mengartikan bahwa ketentuan nomor dua berlaku dalam penelitian ini bahwa $\mathrm{H}_{\mathrm{o}}$ ditolak dan $\mathrm{H}_{\mathrm{a}}$ diterima. Hasil Uji F ini menyatakan bahwa hasil uji secara simultan di atas benar adanya.

Dalam penelian ini diperoleh nilai $F_{\text {hitung }}$ sebesar 19,451 yang lebih besar dari nilai $F_{\text {tabel }}$ sebesar 2,66. Dapat dibuat kesimpulan, bahwa terdapat pengaruh yang linier antara variabel independen dengan variabel dependen.

\section{b. Hasil Uji t (Uji Secara Parsial) \\ Tabel 6 Hasil Uji t (Uji Secara Parsial)}

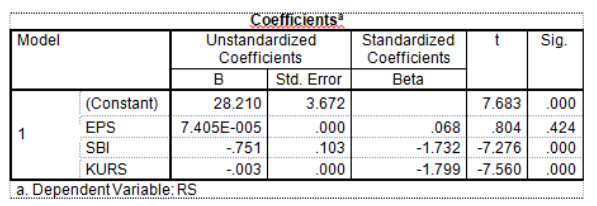

Berdasarkan hasil uji t terlihat variabel independen (suku bunga dan kurs) berpengaruh secara parsial terhadap return saham. Sedangkan variabel earning per share tidak berpengaruh terhadap return saham.

\section{KESIMPULAN DAN SARAN}

\section{A. Kesimpulan}

Berdasarkan hasil analisis mengenai pengaruh earning per share, suku bunga dan kurs terhadap return saham. Berdasarkan hasil uji regresi maka dapat di tarik beberapa kesimpulan bahwa :

1. Hasil uji t menyatakan bahwa variabel earning per share secara parsial tidak memiliki pengaruh terhadap return saham.

2. Hasil uji t menyatakan bahwa variabel suku bunga secara parsial memiliki pengaruh terhadap return saham.

3. Hasil uji t menyatakan bahwa variabel kurs secara parsial memiliki pengaruh terhadap return saham.

4. Hasil uji F menyatakan bahwa variabel earning per share, suku bunga dan kurs secara simultan memiliki pengaruh terhadap return saham.

\section{B. Saran}

Berdasarkan hasil dan analisa yang telah dilakukan peneliti, penelitian ini masih banyak kekurangan dan kelemahan, sehingga masih banyak yang perlu diperbaiki dan diperhatikan lagi untuk penelitian-penelitian berikutnya, beberapa saran perlu ditambahkan guna penelitian yang lebih baik lagi, adapun sarannya sebagai berikut:

1. Menggunakan seluruh perusahaan yang terdaftar di Bursa Efek Indonesia sebagai sampel penelitian sehingga 


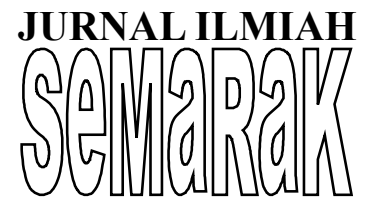

dapat mencerminkan keadaan pasar yang sesungguhnya yang terjadi di Bursa Efek Indonesia.

2. Memperpanjang periode (waktu) penelitian agar menambah jumlah data, sehingga akan mendapatkan hasil data yang lebih normal.

3. Menambah variabel lain yang dapat mempengaruhi Return saham sehingga dapat menjadi luas penelitian.

4. Mencari teori yang relevan dengan keadaan sekarang.

5. Melakukan alat analisis yang lebih baik dan teliti lagi sehingga akan menghasilkan data yang lebih akurat lagi.

\section{DAFTAR PUSTAKA}

Agus Sartono,"Manajemen Keuangan Teori dan Aplikasi", Edisi Keempat, Yogyakarta: BPFE, 2001.

Aminatuzzahra, “Analisis Pengaruh Current Ratio, Debt To Equity Ratio, Total Asset Turnover, Net Profit Margin Terhadap ROE (Studi Kasus Pada Perusahaan Manufaktur GoPublic di BEI Periode 20052009)", Universitas Diponegoro, Semarang, 2010.

Apriliana, Laily, “Analisis Kinerja Keuangan Dan Pengaruhnya Terhadap Harga Saham Pada Perusahaan Lq45 Yang Ada Di Bursa Efek Indonesia", Universitas Gunadarma, Jakarta, 2008

Arthur, J Keown, dkk," Prinsip-prinsip dan Aplikasi Manajemen Keuangan", Penerbit Indeks, Jakarta, 2004.

Bodie,dkk, "Investments Buku I. Edisi Keenam", Salemba Empat, Jakarta, 2006.
Hadi, Kardoyo dan Mudrajad Kuncoro, "Analisis kurs valas dengan pendekatan box jenkins: studi empiris rp/us\$ dan rp/yen", 1983.2-2000.3, Gadjah Mada University, Yogyakarta, 2001.

Halim, Abdul, Eduardus Tandelilin, "Analisis Investasi dan Manajemen Portofolio", Edisi Pertama, BPFE, Yogyakarta, 2001. 106

Haruman, Tendi dan Sri Rahayu, "Penyusun Anggaran Perusahaan", Graha Ilmu, Yogyakarta, 2005.

Ibrahim, Mansor H. and Hassanuddeen Aziz, "Macroeconomic Variables and the Malaysian Equity Market A View Through Rolling Subsamples", Journal of Economic Studies, 30:6-27, 2003.

Ikatan Akuntansi Indonesia, "Standar Akuntansi Keuangan". Jakarta: Salemba Empat, 2007.

Kandir, Serkan Yilmaz, "Macroeconomic Variables, Firm Characteristics and Stock returns: Evidence from Turkey" , International Research Journal of Finance and Economics, 2008.

Karl,E Case dan Fair, C Rai, "Prinsip-prinsip Ekonomi Makro", Prenhalindo, Jakarta 2001.

Keown, et, al., "Dasar-dasar Manajemen Keuangan", PT Raja Grafindo Persada, Jakarta, 2008.

Madura, Jeff. "Manajemen Keuangan Internasioanal", Erlanga, Jakarta, 2003.

Octaviani, Muharni,"Pengaruh Kinerja Keuangan Terhadap Harga Saham Perbankan Di Bursa Efek Indonesia”, Skripsi S-1, Universitas Sumatra Utara, Medan, 2009.

Parulian, Yanto, "Analisis Pengaruh Kurs, Suku Bunga, dan IHSG terhadap Performance Sektor-Sektor 


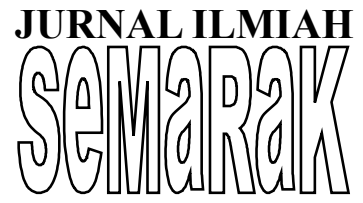

Industri Di Indonesia Selama Periode 1 Januari 1999 sampai 31 Desember 2003", Depok. Universitas Indonesia, 2005.

Prasetiantono,T.A, "Keluar Dari Krisis" : Analsis Ekonomi Indonesia Gramedia Pustaka Utama, Jakarta, 2000.

Perdana, Tito, dkk, "Pengaruh Kinerja Keuangan Dan Beta Saham Terhadap Price To Book Value (Studi pada Perusahaan Real Estate dan Property yang Listed di Bursa Efek Indonesia Periode Tahun 2004-2006)". Jurnal Menejemen, Jakarta, 2008.

Purnawan, Agnes Maria, "Analisi Pengaruh Pergerakan Harga Minyak Mentah Dunia, Kurs, dan IHSG terhadap Pergerakan harga Saham-Saham Pertambangan di Bursa Efek Jakarta", Depok. Universitas Indonesia, 2006. 107

Purnomo, S., \& Pasaribu, V. L. D. (2019). Pergerakan Harga Saham PT Adaro Energy Tbk (ADRO) Pada Pengumuman Dividen Interim Tahun Buku 2018. Jurnal Ekonomi Efektit, 2(4).

Riyadi, Slamet, "Banking Asset and Liability Management", Lembaga Penerbit Fakultas Ekonomi Universitas Indonesia, Jakarta, 2004.

Samsul, "Pasar Modal \& Manajemen Portofolio", Erlangga, Jakarta, 2006.

Santoso, Singgih, "Riset Pemasaran dan Aplikasi Dengan SPSS", Elex Media Komputindo, Jakarta, 2007.

Sawir, Agnes, "Analisis Kinerja Keuangan dan Perencanaan Keuangan Perusahaan". Jakarta:PT Gramedia Pustaka Utama, 2001.

Sinaga, Diana, "Analisis Kinerja keuangan Terhadap Harga Saham Multifinance dan Asuransi yang tercatat di BEJ", Skripsi S-1, Universitas Sumatra Utara, Medan, 2006.
Sitinjak, Kurniasari “ Jurnal Riset Ekonomi dan Manajemen” Vol.3 No.3, 2003.

Subalno, "Analisis Pengaruh Faktor Fundamental Dan Kondisi Ekonomi Terhadap Return Saham (Study Kasus Pada Perusahaan Otomotif dan Komponen Yang Listed di Bursa Efek Indonesia Periode 2003-2007)", Universitas Diponegoro, Semarang, 2009.

Sugiyono, "Metode Penelitian Kuantitatif, Kualitatif, dan R\&D”, Penerbit Alfabeta, bandung, 2007.

Sukirno, Sadono, "Makro Ekonomi Teori Pengantar", PT Raja Grafindo Perkasa, Jakarta, 2004.

Sunariyah, "Pengantar Pengetahuan Pasar Modal", UPP AMP YKPN, Yogyakarta, 2004.

Susilowati, Yeye, "Reaksi Signal Rasio Profitabilitas Dan Rasio Solvabilitas Terhadap Return Saham Perusahaan Profitability And Solvability Ratio Reaction Signal Toward Stock Return Company". Universitas Stikubank, Semarang, 2011.

Tandelilin, Eduardus. 2001. "Analisis Investasi dan Manajemen Portofolio". Edisi Pertama. Yogyakarta: BPFE. 108

Tjiptono Darmadji dan Hendy M Fakhuddin, "Pasar Modal di Indonesia", Salemba Empat, Jakarta, 2001.

Lestari, Murti."Pengaruh Variabel Makro Terhadap Return Saham Di Bursa Efek Jakarta: Pendekatan Beberapa Model", Universitas Kristen Duta Wacana, 2005.

Auliyah, Robiatul dan Hamzah, Ardi. "Analisa Karakteristik Perusahaan, Industri Dan Ekonomi Makro Terhadap Return Dan Beta Saham Syariah Di Bursa Efek Jakarta " Universitas Trunojoyo, 2006.

Widodo Saniman "Analisis Pengaruh Rasio Aktivitas, Rasio Prifitabilitas, Dan Rasio Pasar Terhadap Return Saham Syariah Dalam Kelompok Jakarta Islamic Index (JII) Tahun 
JURNAL ILMIAH

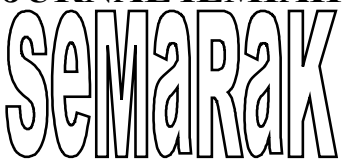

2003

Diponegoro, 2007.

Diponegoro, 2007
P-ISSN 2615-6849, E-ISSN 2622-3686

Jurnal Semarak,Vol. 2,No.3, Oktober 2019, Hal (61- 77)

@ Prodi Manajemen Fakultas Ekonomi Universitas Pamulang

2005" Universitas 